\title{
Parenting and Adult Development: Contexts, Processes, and Products of Intergenerational Relationships
}

\author{
Rob Palkovitz \\ Loren D. Marks \\ David W. Appleby \\ Erin K. Holmes \\ Brigham Young University - Provo, erin_holmes@byu.edu
}

Follow this and additional works at: https://scholarsarchive.byu.edu/facpub

Part of the Other Social and Behavioral Sciences Commons

\section{Original Publication Citation}

Palkovitz, R., Marks, L., Appleby, D., and Holmes, E. K. (2003). Parenting and adult development: Contexts, processes and products of intergenerational relationships. In L. Kuczynski (Ed.) The handbook of dynamics in parent-child relationships (pp. 307-323). Thousand Oaks, CA:

SagePublications.

\section{BYU ScholarsArchive Citation}

Palkovitz, Rob; Marks, Loren D.; Appleby, David W.; and Holmes, Erin K., "Parenting and Adult Development: Contexts, Processes, and Products of Intergenerational Relationships" (2003). Faculty Publications. 4790. https://scholarsarchive.byu.edu/facpub/4790

This Book Chapter is brought to you for free and open access by BYU ScholarsArchive. It has been accepted for inclusion in Faculty Publications by an authorized administrator of BYU ScholarsArchive. For more information, please contact ellen_amatangelo@byu.edu. 


\title{
PARENTING AND
}

\section{Adult Development}

\section{Contexts, Processes, and Products of Intergenerational Relationships}

\author{
Rob Palkovitz \\ LOREN D. MARKS \\ David W. Appleby \\ Erin Kramer Holmes
}

$\mathrm{F}$ or the past 50 years, parenthood has been discussed in social science literature as a context of adult development. Theories, anecdotes, and the opinions of laypersons are nearly unanimous: People who become parents and are involved in the raising of children are transformed and follow a different developmental trajectory from people who do not engage in parenting roles. Erikson (1950) suggested that positive adult development reflects care for the next generation, or "generativity," and that parenthood is "the first, and for many, the prime generative encounter" (Erikson, 1964, p. 130). More recently, parenthood has been described as a necessary but not sufficient condition for the achievement of generativity (Snarey, Son, Kuehne, Hauser, \& Vaillant, 1987). Sociologists and psychologists recently have considered how children provide years of training "opportunities" for parents (Frankel, 1991) and profoundly affect the lives of parents (Ambert, 2001; Palkovitz, 1996, 2002). Daniels and Weingarten (1986) have described parenting as a "powerful generator of adult development" (p. 36). Newman and Newman (1988, p. 313) labeled parenting as a "prime candidate" for stimulating adults' openness to new learning and coping strategies, and P. A. Cowan (1988) suggested that fatherhood presents numerous opportunities for men to experience "increased integration and differentiation, a qualitative developmental change ... [indicating] maturity" (p. 14).

It is evident that the influence of children upon parents entails more than an inadvertent impact on the environment of parents. "Parenthood represents a context, a set of environmental conditions which, if engaged in, will affect the development of involved adults" (Palkovitz, 1996, p. 572). Newman and Newman (1988) state that parenthood "affects 


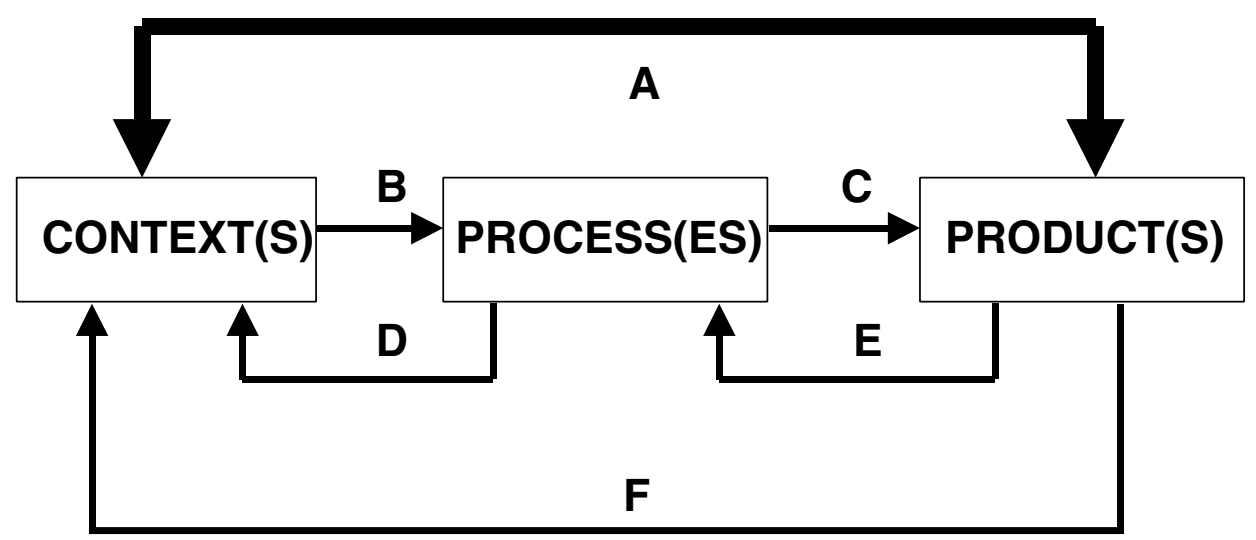

Figure 15.1 A Conceptual Model of Parenting and Adult Development

those who become engaged in it in profound and particular ways" (p. 313). It is likely that the more engaged a parent is, the more his or her adult development will be affected. Because there is a direct relationship between the degree of investment a person places in any developmental context and the outcome that the context affords, it has been hypothesized that the developmental impact of parenting is directly related to its cumulative salience in relation to other contexts of development (Palkovitz, 1996).

Parenting as a context for adult development represents more than a relationship within the parental-child dyad. Parenting involves bidirectional relationships between members of two or more generations; can extend through all of or the major parts of the respective life spans of these groups; may engage a wide variety of institutions (educational, economic, political, and social) within a culture; is embedded in personal, family, and social history (Hareven, 2000); and develops within the natural and designed settings within which the group lives (Lerner, Castellino, Terry, Villarruel, \& McKinney, 1995). Engaged parenting therefore represents a pervasive context and set of ongoing interactions that have the potential to affect both life-span developmental outcomes and changes in life course transitions and trajectories experienced by involved parents. Moreover, children exert active agency through deliberate interventions into their parents' behaviors, beliefs, and attitudes (Kuczynski, Harach, \& Bernardini, 1999; Palkovitz, 2002b).
Although there have been considerable advances in conceptual frameworks for understanding the effects of parenting on adult development (e.g., Ambert, 2001, Kuczynski et al., Palkovitz, 1996), little empirical work has been generated in a manner that reflects our current level of conceptual sophistication. This chapter attempts to summarize pertinent empirical findings, to further refine conceptual constructs, to elaborate on their interactions, and to facilitate understanding of the effects of parenting on adult development.

Sameroff (1975) elaborated a transactional model of development that suggests that parents exert a developmental influence on children that changes over both time and the history of the relationship. Such models have been applied to explain parents' effects on child development. In this chapter, we will review conceptual and empirical literature to demonstrate that there are interdependent, changing, and complex relationships between the contexts, processes, and products of parenting as they pertain to adult development (see Figure 15.1). In particular, the varied contexts of parenting will be shown to exert influence on processes of family interaction (see line B, Figure 15.1), which in turn are related to developmental outcome effects for parents (line C). As the processes of parent-child interaction continue to operate across time, they become part of the context of development (line D). As processes influence products of development, the products exert influences on the processes (line E) and become part of the contexts of development (line F). 
Developmentalists, sociologists, and family scientists measure developmental outcomes at a particular time in an attempt to capture products of the developing context-process interface. A majority of the existing empirical literature examines correlations between contexts and products of parenting and adult development. This pattern of empirical investigation of child effects on adult development parallels the historical development of unidirectional socialization research in early parent-child relations, generating long lists of correlations between assumed antecedents and consequences while ignoring intervening processes (Schaffer, 1984). If any given context were highly and consistently correlated with a particular product, then the processes of parenting and adult development would not be as consequential. Because variability in products is observed within similar contexts, the importance of intervening processes is highlighted. Furthermore, contexts do not create products without intervening processes; there are no direct paths from contexts to products without processes mediating the relationship. Adding a further layer of complexity, the interactions among these elements are continually shifting and unpredictable, partly because of human agency. Specifically, humans make conscious choices about ways to direct their energies and behavior. In doing so, they change the relationships between contexts, processes, and products of development. Social scientists typically discuss contexts of development from the perspective of demographic summary data (e.g., the subjects were middle-class, married couples with children in their teen years). Although these summary data do not capture elaborate differences in the quality of contexts, they do reflect some qualitative aspects. For instance, middle-class families have a different set of resources to draw upon than do working-class families, thereby creating qualitatively different contexts for development. From the perspective of both parents and children, however, the quality of interactions (process variables) more directly captures the texture of life in the family.

One theoretical perspective that focuses on qualitative context-including historical, individual, family, cohort, and generational factors-is the life-course approach. Life-course approaches to understanding development emerged from foundations in family sociology to include interdisciplinary integrations considering individuals in families, in their historical and demographic contexts (Bengtson \& Allen, 1993; Hareven, 1996). Life-course theorists have focused attention on developmental changes that can be viewed as transitions in roles and family careers or trajectories, whereas life-span developmentalists, having roots most directly tied to individual psychology, have focused more attention on products of development that are, in essence, traits or states (Baltes, 1979). Given that difference in approach, developmentalists from the different traditions employ different theoretical constructs, different levels of analysis, distinct conceptualizations of marker variables, and varied methods of assessing and conceptualizing developmental outcomes across disciplines. Both approaches to development offer useful lenses for viewing the effects of children on adult development.

Despite having multiple disciplinary approaches representing rich theoretical, conceptual, and empirical traditions, we know little about the processes of development (Parke, 2002). However, we know much more about contexts of development and products of development. The differences in our knowledge bases between these categories are grounded in current levels of conceptualization, the nature of what is being studied, and ways to operationalize and measure them. Simply stated, many contextual components of development are conceptualized and operationalized as relatively straightforward quantitative variables (often linked to demography). Similarly, because of the developmental histories of our disciplines and the efforts invested in advancing understanding of products of development and ways to measure them, we have a fair number of "outcome" variables that are well operationalized and capable of being tapped through tried and trued psychometrics.

\section{Contexts of Development}

Recent scholarship has highlighted the importance of contexts of development for both 
children (Garcia-Coll et al., 1996) and parents (Palkovitz, 2002b). A few examples make it clear that the context of a parent-child relationship makes a great deal of difference for adult developmental outcomes. In the life-course tradition, it has been well documented that early versus late timing of parenting creates distinctly different life-course experiences for mothers (Burton, 1990) and fathers (Cooney, Pedersen, Indelicato, \& Palkovitz, 1993). Specifically, early childbearing has been associated with lower educational attainment and lower income for both early-timing mothers and fathers. These findings suggest that adult development exerts a reciprocal effect on parenting as well. From a life-span perspective, we know that parenting a difficult baby is associated with significantly greater stress than raising a child with an easy temperament (Thomas \& Chess, 1977). In extreme cases, chronically difficult babies are thought to elicit abusive behavior from parents (Sameroff, 1975). Thus, there is individual variability in the developmental outcome effects for parents who are early timing and late timing, for those who parent easy versus difficult children, and for parents who experience ongoing interaction with their children in many other contexts of development.

The critical point is that contexts of interaction contribute to the meanings that family members create; the cognitive, emotional, and behavioral components (Palkovitz, 1997); and outcomes or sequences that follow any given interaction. These sequences, in turn, contribute to the processes that influence developmental outcomes, or products. The processes of parentchild interaction become part of the relationship's historical context and contribute meaning (cognitively and affectively) to subsequent interactions.

Doherty, Kouneski, and Erickson (1998) suggest that five broad categories of factors interact in influencing responsible fathering. These are father factors, coparental factors, mother factors, child factors, and (general) contextual factors. These factors, if applied to the parenting relationship as a whole, are useful in looking at the context of the parent-child relationship. To adequately depict the adult development effects of parent-child interaction is extremely difficult, considering the complexity of these interactions. Yet, if scholarship does not cope with this complexity, then, given the diversity of parent-child relationships that are both products and producers of multilevel personcontext relations, neither research nor application will be adequate (Lerner et al., 1995).

\section{Father Factors}

What father factors are part of the context of parent-child interaction? We know that men show marked individual (Belsky, Steinberg, \& Draper, 1991) and cultural variation in the expression of paternal care (Marsiglio, Amato, Day, \& Lamb, 2000).

How men see themselves as potential and factual fathers influences father involvement (Palkovitz, 1980, 1997). The father identity is often powerfully influenced by beliefs that are tied to the way that men's current and previous romantic partners have responded to them - and indirectly by their children (Marsiglio \& Cohan, 2000). Fathers come to see themselves, at least in part, based on how they believe others see them, these reflected appraisals being drawn from existing social and/or cultural beliefs and expectations (Marsiglio \& Cohan, 2000). This self-perception and a perceived self-competence in interacting with children is also associated with a father's involvement with his children (Baruch \& Barnett, 1986; McHale \& Huston, 1984; Palkovitz, 1980, 1984) and his success as a father (P. A. Cowan, 1988).

Father role identification, competency, and commitment are also important influences on fathering (Baruch \& Barnett, 1986; InhingerTallman, Pasley, \& Buehler, 1995). These factors, working in conjunction with other interpersonal and contextual factors such as mothers' expectations (Palkovitz, 1984), father's residential status with his children (InhingerTallman et al., 1995; Marsiglio, 1995), gender role (Radin \& Harold-Goldsmith, 1989), father's and mother's relationships with their own parents (Radin, 1994; Snarey, 1993), and father's time availability as it relates to hours of employment (Gottfried, Bathurst, \& Gottfried, 1994; Palkovitz, Christiansen, \& Dunn, 1998), influence paternal engagement in the parenting process, which, in turn, influences adult development. 


\section{Child Factors}

Temperamentally easy children have been characterized by regularity, the tendency to approach novel stimuli, high adaptability, and a generally positive, mild mood. Children who have been described as temperamentally difficult tend to be irregular in terms of their biological functions, frequently withdraw in response to new stimuli, are slow to adapt to change, and often express intense, negative mood (Meyer, 1999). Thomas and Chess (1977) emphasized that child temperament affects parents' confidence, management styles, and level of involvement. Children's developmental status (Parke \& Beitel, 1988), gender (Maccoby, 1998), age (Ambert, 2001; Belsky, 1984), and attachment styles (Ainsworth, Blehar, Waters, \& Wall, 1978) each influence parental interaction. In addition, child factors are influenced by social and physical components such as the family context and the psychosocial and physical climates promoted by the parents.

\section{Mother Factors}

Several factors have been found to influence a mother's involvement in the parenting process and her engagement with the family. Maternal age and maturity level (Burton, 1990), family structure (Aquilino, 1994; Cooney \& Uhlenberg, 1990; Rossi \& Rossi, 1990), and timing and transition to parenthood (Burton, 1990; C. P. Cowan \& Cowan, 1992) create different contexts for mothering processes and developmental outcomes. Maternal employment status and work patterns (Daly, 1996a; Hochschild, 1989; Pleck, 1997), maternal role satisfaction (Rogers \& White, 1998), perceived social support (Coltrane, 1996), mothers' sensitivity and responsiveness to child signals (Ainsworth et al., 1978), and mothers' attachment to children (Ainsworth et al., 1978) each influence patterns of mother-child interaction as well.

Mothers' overall affect and distress (Goldsteen \& Ross, 1989) play a significant role as well. Mothers who are depressed generally appear more irritable and less emotionally available, as well as expressing less warmth when interacting with their children when compared to nondepressed mothers (Downey \& Coyne,
1990). They also have been found to exhibit relatively higher levels of negative affect, vocalize less often, and respond in a slower manner in parent-child interactions (Radke-Yarrow, Nottelman, Belmont, \& Welsh, 1993). Furthermore, they are more likely to ignore their young children, become mentally disengaged, and be less aware of their children's cues during play (A. D. Cox, Puckering, Pound, \& Mills, 1987).

\section{Coparental Factors}

Most empirical data on the relation between marital functioning and parenting behavior originate from studies on the effects of divorce (e.g., Hetherington, 1993), but a smaller number of investigations have been assessments of intact families. This literature, however, has been difficult to interpret because of inconsistent findings (Meyer, 1999). Several studies have found statistically significant positive relationships between marital satisfaction and parents' behavior toward infants and young children. M. J. Cox, Owen, Lewis, and Henderson (1989) reported that mothers who described their relationship with their husbands as close and open also displayed sensitivity and warmth toward their infants during play interactions. Similarly, Jouriles, Pfiffner, and O'Leary (1988) reported that mothers' level of marital discord was positively correlated with their use of disapproval statements directed toward their young sons, as well as with inattentiveness to their young daughters' disruptive behavior. However, other studies of marital satisfaction and maternal behavior have failed to find statistically significant relations or have reported significant negative correlations between marital satisfaction and maternal sensitivity. Some researchers have suggested that mothers may become more involved with their young children to compensate for a less-than-satisfactory marriage. For example, Brody, Pillegrini, and Sigel (1986) reported that maritally distressed mothers generally were more engaged with their schoolaged children during teaching interactions than were mothers who reported relatively higher levels of marital satisfaction (Meyer, 1999).

The quality of father-child relationships, both inside and outside marriage, is more strongly correlated with the quality of the 
coparental relationship than is the mother-child relationship (Belsky \& Volling, 1987; M. J. Cox et al., 1989). Men's attachments to their children appear to be facilitated by their attachment to their wives (Doherty, 1997; Furstenberg \& Cherlin, 1991). When a man's connection to his wife is severed or dramatically altered, the family often fragments and diversifies. Mothers mediate men's relationships with their children by monitoring, supervising, and delegating certain tasks to fathers (Backett, 1987). Furstenberg, Nord, Peterson, and Zill (1983) concluded: "It is apparent that a divorce (or a permanent separation) not only severs the marital bonds, but often permanently ruptures the parent-child relationship, especially if the child is living apart from the father" (pp. 663-664).

There is evidence that even within a satisfactory marital relationship, a father's relationships with his children, particularly young children, are often contingent on the mother's attitudes toward, expectations of (Palkovitz, 1984), and support for fathers, as well as by the extent of her involvement in the labor force (DeLuccie, 1995; Doherty et al., 1998; R. Simons, Whitbeck, Conger, \& Melby, 1990). Marsiglio (1991) found that fathers' involvement with children was more strongly correlated with mothers' characteristics than fathers' characteristics.

Other evidence suggests that the quality of the marital relationship is related to fatherinfant interaction patterns (Amato \& Keith, 1991). In addition, some hold that the fatherchild relationship is altered more than the mother-child relationship by the quality of the marriage (Belsky \& Volling, 1987). Factors such as affective changes in the quality of the parent-child relationship, lack of emotional availability, and less optimal parenting styles have been suggested as potential mechanisms through which marital disruption affects the parenting processes and, subsequently, adult development (Parke, 2002).

Parke's (2002) comprehensive review of fathers and families concluded that successful fathering is more dependent on a supportive marital relationship than is mothering. He attributes this to three factors. First, fathers' level of participation is, in part, influenced by the extent to which the mother permits and encourages participation (Allen \& Hawkins,
1998; Beitel \& Parke, 1998). Second, because the father role is less well articulated and defined than the mother role, spousal support may serve to help crystallize the boundaries of appropriate role behavior. Third, males typically have fewer opportunities to acquire and practice skills that are central to caregiving activities during socialization and therefore may benefit more than mothers from informational support (Parke \& Brott, 1999).

A 7-year longitudinal study by C. P. Cowan and Cowan (1997) examining effects of children on marriage found that childless couples "showed remarkable stability" across time, whereas parents experienced "significant and often disturbing or unexpected shifts" (p. 24). In short, children have a dynamic influence on marriage. They are "unpredictable factors" in both positive and negative ways (Ambert, 2001, p. 66). Purrington's (1980) finding that parents experienced a more expansive range of emotions than non-parents sheds light on the "significant shifts" reported by parents (above). This range of parental emotions, according to Ambert (2001), runs the gambit, "from intense rage" to profound "joy" (p. 59), introducing a pull on adult emotional development.

Parents are also sensitive to social support. A meta-analysis of studies examining the relationship between social support and maternal behavior revealed that perceived emotional and maternal support and maternal sensitivity are significantly correlated (Andreson \& Telleen, 1992). Earlier research conceptualized social support as a buffer that insulates mothers against the influence of stressors that may threaten optimal parenting. R. L. Simons, Lorenz, Wu, and Conger (1993) reported that social support had not only a direct effect on supportive parenting but also an indirect effect through its influence on levels of parental support. Inadequate social support was associated with higher rates of depression and hostility, which in turn were related to mothers' use of ineffective parenting practices. Several studies also suggest that the degree of emotional and social support that fathers provide mothers is related to indices of maternal caregiving competence as well as measures of the quality of infant-parent attachment (Dickie \& Matheson, 1984; Pedersen, 1975). 


\section{General Contextual Factors}

Parental involvement is likely to vary across time, across developmental periods of both parents and children, and in relation to other components of the social ecology and life circumstances. Palkovitz (1997) has documented that the specific context is important in moderating involvement patterns. It is also the case that different types and levels of involvement are appropriate in different settings or contexts. Furthermore, it must be taken into consideration that there are significant differences between individuals. These interindividual differences may mean that a way of expressing involvement that is appropriate with a child is inappropriate with another child or in a different context (Palkovitz, 1997).

The variability in contexts of parent involvement is extensive. Persons engaging in parenting roles vary by marital status (Amato, 2000; Aquilino, 1994; Cherlin, 1992; Cooney \& Uhlenberg, 1990; Rossi \& Rossi, 1990), marital quality (C. P. Cowan \& Cowan, 1992), type of parenting relationship to child (Castro \& Bumpass, 1989), legality of parental status (Marsiglio, 1995), residential status (Glick, 1989; Petersen \& Zill, 1986), educational level (Pleck, 1997), and employment status (Christiansen \& Palkovitz, 2001). Other dimensions of contextual difference include variables such as income, parents' relationship with their own parents (Rossi \& Rossi, 1990; Snarey, 1993), supports and hindrances to involvement (Allen \& Hawkins, 1999), personality, health, range and types of involvement engaged in (Pleck, 1997), predominant parenting style (Baumrind, 1971), cultural background, individual skill levels, and motivation (Parke, 2002). Although this list is not exhaustive, it does represent variables that are reported frequently in various studies of parent involvement. Table 15.1 lists some of the characteristics that affect parents' involvement across time. Thus, answers to the question, "What does it mean when we say that a parent is more or less involved in child rearing?" depend in part on the current status of an individual parent at the time that we are assessing their involvement in an interdependent and dynamic array of relationships to the child and others in the family and community context.

\section{Processes of Development}

In the professional developmental literature, processes of development often are contested ground: They are more complex, organic, interpersonal, fluid, and controversial than many of the variables that fall into the context and product categories. Although we may have some general agreement concerning some of the process variables, they are often difficult to describe in detail or to measure in quantifiable metrics. For example, we know that good fathering is desirable for children, mothers, communities, and fathers themselves (Palkovitz, 2002a), but it is challenging to describe the processes of good fathering. We are much better able to discuss correlations between contextual variables and developmental outcomes (products) than to elucidate the processes that yield the developmental products in the contexts.

Processes can exert both direct and indirect effects on products of development. According to Barnard and Martell (1995), mothering itself "is learned in the process of interaction with the individual parented" (p. 22, emphasis added). In this section, we review a variety of parent-child processes and the biological, behavioral, psychological, moral, and social influences of these processes on parents. Palkovitz's (1997) work indicates that processes of parental involvement have behavioral, cognitive, and affective components.

\section{Behavioral Contributions to Processes}

In connection with behavior, it is important to note that parental behavior typically has been studied only one domain at a time; rarely have studies focused on multiple dimensions of behavior simultaneously (Barnard \& Martell, 1995; Radke-Yarrow, 1991). Thus, although research regarding different domains of behavior (e.g., monitoring, caregiving, and playing, as discussed below) is available, extant work tells us little about potential interactions and correlations across these domains.

\section{Monitoring}

With regard to monitoring behaviors, new mothers have been reported to "visually check 
Table 15.1 A Partial Listing of Sources of Variability in Parent Involvement Contexts

\begin{tabular}{|c|c|}
\hline Child characteristics & Parent's personal factors \\
\hline Gender & Functionality \\
\hline Age & Preparation for parenthood \\
\hline Personality & Experience in caregiving \\
\hline Developmental status & Knowledge of child development \\
\hline \multirow[t]{2}{*}{ Health } & Relational style \\
\hline & Motivation \\
\hline Parent's demographic factors & Personality \\
\hline Age & Skills/abilities \\
\hline Education & View of parenting role \\
\hline Income & Parenting identity \\
\hline Marital status & Cultural background \\
\hline \multicolumn{2}{|l|}{ Single } \\
\hline Cohabiting & Competing or complementary role demands \\
\hline Engaged & Family \\
\hline Married & Husband/wife \\
\hline Separated & Son/daughter \\
\hline Divorced & Brother/sister \\
\hline Re-cohabiting & Uncle/aunt \\
\hline Remarried & Work \\
\hline Relationship to child(ren) & Hours working \\
\hline Biological parent & Job-related stress \\
\hline Social parent & Community \\
\hline \multirow{2}{*}{\multicolumn{2}{|c|}{ Involvement in organizations }} \\
\hline & \\
\hline Co-residential & Relational factors \\
\hline Nonresident, but nearby & Partner/significant other \\
\hline Nonresident and distant & Marital status \\
\hline \multirow{5}{*}{$\begin{array}{l}\text { Timing of transition to parenthood } \\
\text { Early } \\
\text { On time } \\
\text { Late }\end{array}$} & Relational quality \\
\hline & Degree of gatekeeping \\
\hline & Relationship with own parents \\
\hline & Primacy of modeling vs. reworking \\
\hline & Degree of warmth vs. emotional distance \\
\hline \multirow{7}{*}{$\begin{array}{l}\text { Employment status } \\
\text { Voluntarily unemployed } \\
\text { Involuntarily unemployed } \\
\text { Part-time employed } \\
\text { Full-time employed } \\
\text { Multiple jobs }\end{array}$} & Level of conflict \\
\hline & Siblings/extended family \\
\hline & Social supports \\
\hline & \\
\hline & Parent involvement \\
\hline & Frequencies \\
\hline & Range of behaviors \\
\hline Cultural identity & Quality of interactions \\
\hline Religiosity & Meaning of involvement \\
\hline
\end{tabular}

[on their] infant's well-being about every 20 seconds" (Barnard \& Martell, 1995, p. 13). Mothers typically monitor children's well-being consistently even before children are fully ambulatory. Although less is known about later child-monitoring patterns of mothers, child characteristics such as temperament, activity level, recreational preferences, and propensity to engage in risk-taking behavior influence maternal monitoring behaviors well beyond infancy.

\section{Caregiving}

Caregiving behaviors and their origins and meanings are prevalent topics in the parenting literature. Although the most basic temporal 
needs of children are universal, in North American culture caregiving tasks are performed disproportionately by women generally and mothers specifically (Coltrane, 1996; Hochschild, 1989; Pleck, 1997). Most interpretive scholarship on parenting argues that a primary reason for this gender imbalance is the North American dominant ideal of intensive mothering, in which "the good mother" is "selfsacrificing" and "devoted to the care of others" (Arendell, 2000, p. 1194; see also Hays, 1996; Thurer, 1994). Ideals of intensive mothering, coupled with strong prescriptions for the working father (Christiansen \& Palkovitz, 2001), help to explain some of the observed discrepancies in gendered divisions of caregiving. The implications and effects of the paragon of the intensive mother extend into issues of child care, maternal employment, gendered division of labor, role expectations, and beyond. Heated debate surrounding this ideal will continue to animate scholarship for years to come (Glenn, Chang, \& Forcey, 1994; Hoffnung, 1997).

Although father involvement is likely to be limited relative to mother involvement, recent scholarship indicates that there are no significant gender differences in parenting competency (Parke, 2002), affirmatively answering Snitow's (1992) hypothetical query, "Can men really nurture?" (p. 42). Male nurturance and positive father-child interaction certainly exist, although the need is far from met (Popenoe, 1996). Although many fathers do nurture, it is vital to note that there are gender differences in styles of parent-child interaction.

\section{Playing}

There is perhaps no behavioral domain where gendered differences are more pronounced in the empirical literature than parent-child play. Parke (2002) reviewed approximately a dozen studies that collectively identify mother-father differences in terms of both relative quantity and quality of play, including "more bouncing and lifting games" and more "physical play" by fathers. Parke concluded:

In all studies reviewed, a reasonably consistent pattern emerges: Fathers are tactile and physical, and mothers tend to be verbal, didactic, and toy-mediated in their play. Clearly, infants and young children experience not only more stimulation from their fathers, but a qualitatively different stimulatory pattern.

On a related note, Maccoby (1998, p. 271) has posited that fathers "may be more susceptible to being aroused into states of positive excitement" than mothers - a hypothesis that Parke identified as consistent with other documented gender differences.

The monitoring, caregiving, and playing behaviors reviewed above are significant in that what one does with vested time, interest, and energy influences the sense of who one is. In this sense, even the most ordinary parental tasks may influence and shape adult identity and development across time.

\section{Psychological Contributions to \\ Process and Identity Formation}

The most salient factor in identity formation for women with children is mothering; it is even more salient than marital status or occupation (Rogers \& White, 1998). The potency of mothering over career in identity formation persists despite a tripling of the American maternal employment rate over the last three decades (Spain \& Bianchi, 1996) and the powerful pull of North American consumerism on parents (Dienhart \& Daly, 1997). An illuminating reason for this salience may be that mothering is "the main vehicle through which [children] first form their own identities" (Forcey, 1994, p. 357). It is probable that many women find mothering most significant because it is through mothering that they most profoundly affect (and indeed give life to) the next generation. The related theme of Eriksonian generativity has received recent attention in fathering scholarship as well (e.g., Hawkins, Christiansen, Sargent, \& Hill, 1993; Hawkins \& Dollahite, 1997; Palkovitz, 2002; Snarey, 1993), and similar identity patterns have been found in some fathers (Marks \& Dollahite, 2001). In fact, Palkovitz (2002) found that involved fathers viewed fathering to be the primary factor shaping their lives.

Turning to the themes of context, processes, and products, Barnard and Martell (1995) 
have noted, "The constructs of mother role attainment and maternal identity are closely linked and are difficult to describe separately" (p. 7). The key distinction may lie in the definition of role attainment as a process (Mercer, 1985 , p. 198), whereas identity may be viewed as a product of this process. More specifically, "Identity means that a woman has a sense of comfort in the role of mother. She sees herself as a mother rather than being 'like' a mother" (Barnard \& Martell, 1995, p. 7, emphasis added). The processes of role attainment represent the journey; a positive identity as a parent is the destination.

\section{Biological Contributions to Process}

All mothers experience biological changes during pregnancy, but these changes do not necessarily influence mothers in uniform ways. Although there are many unavoidable physiological changes following conception, some mothers choose to make additional healthrelated adjustments during pregnancy. Rubin's (1984) qualitative work indicates that in the first trimester, many expectant mothers become more concerned with healthy eating habits and stop or curtail the use of tobacco, alcohol, and other deleterious substances. Thus, both direct and indirect child effects on mothers' adult development may emerge months before the actual birth.

Palkovitz's (2002) qualitative study of fathers found that the birth, presence, and actions of children frequently influence health-related changes in fathers (e.g., the reduction or cessation of alcohol, tobacco, and/or illegal drug use), as well as social changes such as decreases in "the party lifestyle" or gang activity. It is significant that the fathers made changes for the sake of their children that they did not previously make for their partners or for themselves. Actively engaged fathers also discussed the need to stay in shape so that they could participate in physically demanding activities with their children as they grow (and as the fathers age).

\section{Child Contributions to}

\section{Process in Parental Values and Beliefs}

Research consistently indicates that many values and beliefs are transmitted by parents to their children through example, instruction, and correction (Grusec, Goodnow, \& Kuczynski, 2000), and Wilson's The Moral Sense (1996) presented evidence that children's sense of moral development is significantly influenced by parents as well. Less attention has been given the to the influence of children on parental values and beliefs. Ta, Kuczynski, Bernardini, and Harach (1999) reported from their review that parents' values and beliefs may be selectively influenced by their children. Although some studies indicate that parents are least likely to be influenced by adolescents in areas such as politics and religion, even in these areas child influence on parents emerges in some studies (Marks \& Dollahite, 2001; Palkovitz, 2002b). It is interesting to note, for example, that parents attend church more regularly than adults without children, particularly in the light of the finding that $90 \%$ of American parents want their children to have a religious education of some sort (Nock, 1998). Therefore, although adolescents may have little direct, intentional influence on their parents' beliefs, parents with young children may become increasingly or newly active in a faith community because of their desire for their child to be involved (e.g., Palkovitz \& Palm, 1998). Child-influenced religious involvement can lead to more in-depth religious commitment on the part of the parent, and this involvement has numerous documented implications for adult development in the areas of physical health, psychological health, and social relationships (Marks, 2001).

\section{Children's Contributions to \\ Processes of Socialization}

For many parents, expectancy marks the beginning of a social transition. Barnard and Martell (1995) emphasize that for mothers-tobe, pregnancy-related "changes in ... relationships [and] lifestyle ... represent both loss and change" (p. 6). First-time mothers often seek to form or intensify friendships with women who are already mothers in an effort to find psychological and social support as well as practical advice. Mothers may also weaken relationships with those they perceive to be potentially detrimental to their child, and they may seek to promote their child's acceptance into the family 
and kin network even before delivering (Arendell, 2000).

Following delivery, mothers face additional social changes that may include the abandonment or curtailment of employment, along with the loss of work-related networks. Other personal activities may fall by the wayside because of decreases in recreational time, money, and energy. Although fathers' activities are affected, "mothers' activities are even more affected than fathers" (Ambert, 2001, p. 52).

As children develop and seek out personally appealing peers and activities, they influence their parents (again, mothers more than fathers) by providing contact with the parents of their peers (Muller \& Kerbow, 1993). This contact allows parents to remain better informed of extrafamilial socialization influences and provides additional opportunities for cooperation and collaboration (Ambert, 2001), as well as community involvement (Palkovitz, 2002). Children's activities can change after relatively brief periods of time (e.g., a youth league soccer season), and relationships among adults at children's events tend to be activity centered. Therefore, although parents may experience a broader social network by interacting with the parents of other children, the friendships developed tend to be more transient and less intimate than adult relationships that are not forged around child activities (Palkovitz, 2002b).

\section{Cognitive Processes}

Pridham, Denney, Pascoe, Chiu, and Creasey (1995) have stated that "The problem-solving processes a mother uses and the solutions she generates in response to a childrearing problem can be viewed as components of parenting style. These processes and solutions structure the child's learning and ultimately shape how the child problem solves intergenerational problems" (p. 786, emphasis added). Other cognitive processes involved in parent-child relationships include engagement in more probabilistic thinking (Newman \& Newman, 1988), dialectical thinking (Hoffman \& Mannis, 1978), more anticipation of the future (Newman \& Newman, 1988), greater allocentrism (Hooker \& Fiese, 1993), and disequilibrium and reorganization of thinking (P. A. Cowan, 1988). Parents also engage in direct learning of new content as they engage with their children in pursuing children's hobbies or interests (Palkovitz, 2002b).

\section{Qualitative Contributions to Understanding Process}

Daly (1992) noted that qualitative research is particularly well suited for exploring processes within families. Although there is still a relative dearth of qualitative data, a recent and growing body of qualitative literature explores the relationships between parenting contexts, processes, and products (Daly, 1992; Dienhart, 1998; Deinhart \& Daly, 1997; Dollahite, Marks, \& Olson, 1998; Holmes, 2001; Latshaw, 1998; Marks \& Dollahite, 2001; Palkovitz, 2002; Palkovitz \& Palm, 1998). These studies represent a new breed of scholarship that is targeted at exploring and describing intergenerational relationships and development and is showing the potential to bring greater conceptualization and understanding to the processes of family life.

Palkovitz's (2002b) qualitative analysis of detailed structured interviews with 40 involved fathers suggests various processes that facilitate adult development through parental involvement. Those processes include, but are not limited to, acceptance of parental responsibility; regular, active engagement with children; recognizing the asymmetry of parent-child relationships in regard to responsibility for caregiving; frequent evaluation of parental role enactment in relation to children's developmental status and needs; planning; monitoring; formation of close affective ties to children; involvement in community roles and social relationships that are initiated and maintained by parental status and roles; and parents' sense of personal growth and satisfaction as a result of actively engaging in parenting behaviors and roles. Such processes elude quantification and study through traditional "ticks and clicks" means of assessing parent-child interaction (Hawkins \& Palkovitz, 1999).

Holmes (2001) investigated relationships between marital and parental roles and how relationships mediate interactions between the contexts and products of parenting and adult development. Holmes found that processes 
interact in a manner that is not strictly additive; moods and emotions in relationships are affected by the moods and emotions of others in their interactions. Through the actions and emotions of others, and despite one's immediate mood, one's moods, perceptions, and behaviors can change. Holmes has labeled the interactive quality of such interpersonal relationships "synergy." This synergy can be both positive and negative, and it depends on family members' emotions and actions. For example, fathers perceived (a) the relationships between maternal expectations and the paternal role, (b) maternal appreciation for the paternal role, (c) maternal authority, (d) instruction and guidance, (e) negative aspects of the co-parental relationship, (f ) positive aspects of the co-parental relationship, and (g) fathers' perceptions of the paternal role-as related to the co-parental relationship - as interacting with and molding the synergy of families. Succinctly stated, family synergy is a process that affects both contexts and products of parent-child interactions and, ultimately, parents' adult development.

\section{Products of Development}

As Kuczynski notes in the introductory chapter of this volume, although there has been great progress made in the conceptualization of bidirectionality, this has not been reflected in empirical research. Although bidirectionality is now a mainstream concept, Kuczynski et al. (1999) noted that many studies do little more than pay lip service to bidirectionality as a causal concept in their research questions and issues, referring to it primarily in discussions concerning the limitations of findings. A review of the empirical literature looking at the effects of children on adult's development leaves major questions regarding the extent to which adult development is shaped by parenting. The most recent reviews (Ambert, 2001; Palkovitz, 1996) have little direct evidence to offer. Theoretical and anecdotal approaches are more abundant than empirical evidence.

Although certain contexts significantly correlate with certain outcomes (products), these correlations are well established only in connection with child outcomes; adult/parent developmental outcomes remain a frontier for empirical investigation. An interesting observation is that this trend parallels the development of the "child outcome" literature (Schaffer, 1984). Although extant data are not capable of demonstrating causal effects of parenting on adult development (Palkovitz, 1996), there are a few correlations between the contextual variables of parenting and adult development outcomes (represented by line A in Figure 15.1). Hoffman and Mannis (1978) found greater levels of dialectical thinking in parents. Heath (1978, 1991) and Hooker and Fiese (1993) reported greater allocentrism and perspective taking ability in parents, and Heath (1991) observed greater levels of self-awareness in parents compared to non-parents. Several investigators have noted increased self-competence in parents (Heath, 1978; Hoffman \& Mannis, 1978; Palkovitz, 1994). Parents have been reported to manifest differences in identity development (P. A. Cowan, 1988; Heath, 1978; Hoffman \& Mannis, 1978), generativity (Hooker \& Fiese, 1993; Palkovitz, 1994; Snarey, 1993), and sextyping (P. A. Cowan, 1988; Palkovitz, 1984; Palkovitz \& Copes, 1988). Parents also have been reported to exhibit greater levels of responsibility than non-parents (Daniels \& Weingarten, 1988; Hooker \& Fiese, 1993; Palkovitz, 1994). For additional reviews, see Ambert (2001) and Palkovitz (1996, 2002b).

Although mothering has long been viewed as central to adult development in women (Arendell, 2000), newly emerging qualitative work indicates that men also perceive that direct engagement in parenting roles, behaviors, and interaction with children motivates developmental change in themselves as adults and that men see fathering as a foundational force in shaping their own development (Palkovitz, 2002b). Parenting defines much of men's identity (Minton \& Pasley, 1996), takes much of their time and energy (Dienhart \& Daly, 1997), and shapes their daily schedules (Daly, 1996a, 1996b). In summary, parenting influences adult developmental outcomes for women and men (Ambert, 2001; Palkovitz, 1996). Furthermore, although the story cannot be elaborated here, involved fathers perceive that active engagement in parenting anchored their mental, physical, and relational life. Children changed men's 
foci, their lifestyles, their family relationships, their work lives, their community involvement, their health habits, their morals and values, their emotional lives, and their marriages (Palkovitz, 2002b).

The transformations perceived to be brought about by actively engaging in parenting children represent many positive demand characteristics as well as some significant challenges, hassles, energy demands, resource drains, unmet needs, and associated fears. Engaged parents are drawn into greater levels of integration and differentiation than they have experienced previously. In essence, they mature (Allport, 1961). Some maturation is manifested in virtually every realm of development. This is not to suggest that all changes associated with parenting children are perceived by parents to be pleasant or positive. However, in the overall balance, many view parenting to be a valuable shaper of their lives, for the better (Ambert, 2001; Palkovitz, 2002b).

\section{Conclusion}

This chapter has argued that contexts, processes, and products of parent-child relationships interact in complex and changing configurations to affect the adult development of parents. What should be clear from this review is that it is not just that "children affect parents" in a way that simply reverses the more traditional social mold perspective that parents socialize children (Peterson \& Rollins, 1987). Qualitative data and meta-analyses of existing quantitative data paint the picture that active engagement in parenting roles and behaviors creates a varied, multilayered context of relationships, interactions, roles, social supports, and challenges that span significant periods of time in parents' lives. Furthermore, parenting matters: Parents are motivated to provide for, protect, nurture, instruct, and facilitate the development of their children. Because active engagement in parenting roles is often highly motivated and can span a period of decades, it creates contexts, processes, and products that are multidimensional, plastic, relationally embedded, socially constructed, and life transforming. Much of parent engagement takes place during the eras of young adulthood and middle age, both of which are relative frontiers in developmental scholarship.

A particularly promising trend in conceptualization and empirical investigation is the employment of purposive qualitative research. Qualitative investigations have the potential to further understanding of parent-child processes and to bring more refined conceptualization and specificity that will generate measures and empirical work focused on the process-product interface. This is the area of parenting and adult development most in need of advancement.

\section{REFERENCES}

Ainsworth, M.D.S., Blehar, M. C., Waters, E., \& Wall, S. (1978). Patterns of attachment. Hillsdale, NJ: Erlbaum.

Allen, S. M., \& Hawkins, A. J. (1999). Maternal gatekeeping: Mothers' beliefs and behaviors that inhibit greater father involvement in family work. Journal of Marriage and the Family, 61, 199-212.

Allport, G. W. (1961). Pattern and growth in personality. New York: Holt, Rinehart \& Winston.

Amato, P. R. (2000). The consequences of divorce for adults and children. Journal of Marriage and the Family, 62, 1269-1287.

Amato, P., \& Keith, B. (1991). Consequences of parental divorce for children's well-being: A meta-analysis. Psychological Bulletin, 110, 26-46.

Ambert, A. (2001). The effect of children on parents (2nd ed.). New York: Haworth.

Andreson, P. A., \& Telleen, S. L. (1992). The relationship between social support and maternal behaviors and attitudes: A meta-analytic review. American Journal of Community Psychology, 20, 753-774.

Aquilino, W. S. (1994). Impact of childhood family disruption on young adults' relationship with parents. Journal of Marriage and the Family, 56, 295-313.

Arendell, T. (2000). Conceiving and investigating motherhood: The decade's scholarship. Journal of Marriage and the Family, 62, 1192-1207.

Backett, K. (1987). The negotiation of fatherhood. In C. Lewis \& M. O'Brien (Eds.), Reassessing fatherhood: New observations on father and the modern family (pp. 74-90). Newbury Park, CA: Sage.

Baltes, P. B. (1979). Life-span developmental psychology: Some converging observations on history and theory. In P. B. Baltes \& O. G. Brim, Jr. (Eds.), Life-span development and behavior (Vol. 2, pp. 255-279). New York: Academic Press. 
Barnard, K. E., \& Martell, L. K. (1995). Mothering. In M. H. Bornstein (Ed.), Handbook of parenting (Vol. 3, pp. 3-26). Mahwah, NJ: Erlbaum.

Baruch, G. K., \& Barnett, R. C. (1986). Fathers' participation in family work and children's sex-role attitudes. Child Development, 57, 1210-1223.

Baumrind, D. (1971). Current patterns of paternal authority. Developmental Psychology Monographs, 4, 1-24, 99-103.

Belsky, J. (1984). The determinants of parenting: A process model. Child Development, 55, 83-96.

Belsky, J., Steinberg, L., \& Draper, P. (1991). Childhood experience, interpersonal development, and reproductive strategy: An evolutionary theory of socialization. Child Development, 62, 647-670.

Belsky, J., \& Volling, B. L. (1987). Mothering, fathering, and marital interaction in the family triad during infancy. In P. W. Berman \& F. A. Pedersen (Eds.), Men's transition to parenthood: Longitudinal studies of early family experience (pp. 37-63). Hillsdale, NJ: Lawrence Erlbaum.

Bengtson, V., \& Allen, K. R. (1993). The life course perspective applied to families over time. In P. G. Boss, W. J. Doherty, R. LaRossa, W. R. Schumm, \& S. K. Steinmetz (Eds.), Sourcebook of family theories and methods: A context approach (pp. 469-499). New York: Plenum.

Beitel, A., \& Parke, R. D. (1998). Maternal and parental attitudes as determinants of father involvement. Journal of Family Psychology, 12, 268-288.

Brody, G. H., Pillegrini, A. D., \& Sigel, I. E. (1986). Childrearing history, marital quality, and maternal affect: Intergenerational transmission in a low-risk sample. Development and Psychopathology, 32, 905-913.

Burton, L. M. (1990). Teenage childbearing as an alternative life-course strategy in multigenerational black families. Human Nature, 1(2), 123-143.

Castro, M. T., \& Bumpass, L. L. (1989). Recent trends in marital disruption. Demographics, 26, $37-51$.

Cherlin, A. J. (1992). Marriage, divorce, remarriage. Cambridge, MA: Harvard University Press.

Christiansen, S., \& Palkovitz, R. (2001). Providing as a form of paternal involvement: Why the "good provider" role still matters. Journal of Family Issues, 22, 84-106.

Coltrane, S. (1996). Family man: Fatherhood, housework, and gender equity. New York: Oxford University Press.

Cooney, T. M., Pedersen, F. A., Indelicato, S., \& Palkovitz, R. (1993). Timing of fatherhood: Is "on-time" optimal? Journal of Marriage and the Family, 55, 205-215.

Cooney, T. M., \& Uhlenberg, P. (1990). The role of divorce in men's relations with their adult children after mid-life. Journal of Marriage and the Family, 52, 677-688.

Cowan, C. P., \& Cowan, P. A. (1992). When partners become parents. New York: Basic Books.

Cowan, C. P., \& Cowan, P. A. (1997). Working with couples during stressful transitions. In S. Dreman (Ed.), The family on the threshold of the 21st century (pp. 17-48). Mahwah, NJ: Erlbaum.

Cowan, P. A. (1988). Fatherhood as an opportunity for adult development. In P. Bronstein \& C. P. Cowan (Eds.), Fatherhood today: Men's changing role in the family (pp. 13-35). New York: John Wiley \& Sons.

Cox, A. D., Puckering, C., Pound, A., \& Mills, M. (1987). The impact of maternal depression in young children. Journal of Child Psychology, Psychiatry, and Allied Disciplines, 28, 917-928.

Cox, M. J., Owen, M. T., Lewis, J. M., \& Henderson, V. K. (1989). Marriage, adult adjustment, and early parenting. Child Development, 60, 1015-1024.

Daly, K. (1992). The fit between qualitative research and characteristics of families. In J. F. Gilgun, K. Daly, \& G. Handel (Eds.), Qualitative methods in family research (pp. 3-11). Newbury Park, CA: Sage.

Daly, K. J. (1996a). Families and time: Keeping pace in a hurried culture. Thousand Oaks, CA: Sage.

Daly, K. J. (1996b). Spending time with the kids: Meanings of family time for fathers. Family Relations, 45, 466-476.

Daniels, P., \& Weingarten, K. (1988). The fatherhood click: The timing of parenthood in men's lives. In P. Bronstein \& C. P. Cowan (Eds.), Fatherhood today: Men's changing role in the family. New York: John Wiley \& Sons.

DeLuccie, M. F. (1995). Mothers as gatekeepers: A model of maternal indicators of father involvement. The Journal of Genetic Psychology, 16, 115-131.

Dickie, J. R., \& Matheson, P. (1984, August). Mother-father-infant: Who needs support? Paper presented at the meeting of the American Psychological Association, Toronto.

Dienhart, A. (1998). Reshaping fatherhood: The social construction of shared parenting. Thousand Oaks, CA: Sage.

Dienhart, A., \& Daly, K. (1997). Men and women cocreating father involvement in a nongenerative culture. In A. J. Hawkins \& D. C. Dollahite (Eds.), Generative fathering: Beyond deficit perspectives (pp. 147-164). Thousand Oaks, CA: Sage.

Doherty, W. J. (1997). The best of times and the worst of times: Fathering as a contested area of academic discourse. In A. J. Hawkins \& D. C. Dollahite (Eds.), Generative fathering: Beyond deficit perspectives (pp. 217-227). Thousand Oaks, CA: Sage.

Doherty, W. J., Kouneski, E. F., \& Erickson, M. F. (1998). Responsible fathering: An overview and 
conceptual framework. Journal of Marriage and the Family, 60, 277-292.

Dollahite, D. C., Marks, L. D., \& Olson, M. M. (1998). Faithful fathering in trying times: Religious beliefs and practices of Latter-day Saint fathers of children with special needs. Journal of Men's Studies, 7, 71-94.

Downey, G., \& Coyne, J. C. (1990). Children of depressed parents: An integrative review. Psychological Bulletin, 108, 50-76.

Erikson, E. (1950). Childhood and society. New York: Norton.

Erikson, E. (1964). Insight and responsibility: Lectures on the ethical implications of psychoanalytic insight. New York: Norton.

Forcey, L. R. (1994). Feminist perspectives on mothering and peace. In E. N. Glenn, G. Chang, \& L. R. Forcey (Eds.), Mothering: Ideology, experience, and agency (pp. 355-376). New York: Routledge.

Frankel, J. (1991). On being reared by your children: State of the art as reflected in the literature. Free Inquiry in Creative Sociology, 19, 193-200.

Furstenberg, F. F., Jr., \& Cherlin, A. (1991). Divided families: What happens to children when parents part? Cambridge, MA: Harvard University Press.

Furstenberg, F. F., Jr., Nord, C. W., Peterson, J. L., \& Zill, N. (1983). The life course of children of divorce: Marital disruption and parental contact. American Sociological Review, 48, 656-668.

Garcia-Coll, C., Lamberty, G., Jankins, R., McAdoo, H. P., Crnic, K., Wasik, B. H., et al. (1996). An integrative model for the study of developmental competencies in minority children. Child Development, 67, 1891-1914.

Glenn, E. N., Chang, G., \& Forcey, L. R. (Eds.). (1994). Mothering: Ideology, experience, and agency. New York: Routledge.

Glick, P. C. (1989). Remarried families, stepfamilies, and stepchildren: A brief demographic profile. Family Relations, 38, 24-27.

Goldsteen, K., \& Ross, C. E. (1989). The perceived burden of children. Journal of Family Issues, 10, 504-526.

Gottfried, A. E., Bathurst, K., \& Gottfried, A. W. (1994). Role of paternal and dual-earner employment status in children's development: A longitudinal study from infancy through early adolescence. In A. E. Gottfried \& A. W. Gottfried (Eds.), Redefining families: Implications for children's development (pp. 55-97). New York: Plenum.

Grusec, J. E., Goodnow, J. J., \& Kuczynski, L. (2000). New directions in analyses of parenting contributions for children's acquisition of values. Child Development, 71, 204-211.

Hareven, T. K. (1996). Life course. In J. I. Birren (Ed.), Encyclopedia of gerontology (Vol. 2, pp. 31-40). San Diego: Academic Press.

Hareven, T. K. (2000). Families, history, and social change. Boulder, $\mathrm{CO}$ : Westview.
Hawkins, A. J., Christiansen, S. L., Sargent, K. P., \& Hill, J. E. (1993). Rethinking fathers' involvement in childcare: A developmental perspective. Journal of Family Issues, 14, 531-549.

Hawkins, A. J., \& Dollahite, D. C. (Eds.). (1997). Generative fathering: Beyond deficit perspectives. Thousand Oaks, CA: Sage.

Hawkins, A. J., \& Palkovitz, R. (1999). Beyond ticks and clicks: The need for more diverse and broader conceptualizations and measures of father involvement. Journal of Men's Studies, 8, 11-32.

Hays, S. (1996). The cultural contradictions of mothering. New Haven, CT: Yale University Press.

Heath, D. (1978). What meaning and effects does fatherhood have for the maturing of professional men? Merrill-Palmer Quarterly, 24, 265-278.

Heath, D. (1991). Fulfilling lives. San Francisco: Jossey-Bass.

Hetherington, E. M. (1993). An overview of the Virginia Longitudinal Study of Divorce and Remarriage with a focus on early adolescence. Journal of Family Psychology, 7, 39-56.

Hochschild, A. (1989). The second shift: Working parents and the revolution at home. New York: Viking.

Hoffman, L. W., \& Mannis, J. D. (1978). The value of children in the United States: A new approach to the study of fertility. Journal of Marriage and the Family, 41, 583-596.

Hoffnung, M. (1997). Motherhood: Contemporary conflict for women. In S. J. Ferguson (Ed.), Shifting the center: Understanding contemporary families (pp. 277-291). Mountain View, CA: Mayfield.

Holmes, E. K. (2001). When mom is happy everyone is happy: Men's perceptions of how women support and hinder men's involvement in parenting. Unpublished master's thesis, University of Delaware.

Hooker, K., \& Fiese, B. H. (1993, March). Temporal perspectives on changes in self related to parenting. Paper presented as part of a symposium at the biennial meetings of the Society for Research in Child Development, New Orleans, LA.

Inhinger-Tallman, M., Pasley, K., \& Buehler, C. (1995). Developing a middle-range theory of father involvement postdivorce. In W. Marsiglio (Ed.), Fatherhood: Contemporary theory, research, and social policy (pp. 57-77). Thousand Oaks, CA: Sage.

Jouriles, E. N., Pfiffner, L. J., \& O'Leary, S. G. (1988). Marital conflict, parenting, and toddler conduct problems. Journal of Abnormal Child Psychology, 16, 197-206.

Kuczynski, L., Harach, L., \& Bernardini, S. C. (1999). Psychology's child meets sociology's child: Agency, influence, and power in parentchild relationships. In C. L. Shehan (Ed.), Through the eyes of the child: Re-visioning 
children as active agents of family life (pp. 21-52). Stamford, CT: JAI.

Latshaw, J. (1998). The centrality of faith in fathers' role construction: The faithful father and the Axis Mundi paradigm. Journal of Men's Studies, 7, 53-70.

Lerner, R., Castellino, D., Terry, P., Villarruel, F., \& McKinney, M. (1995). Developmental contextual perspective on parenting. In M. H. Bornstein (Ed.) Handbook of parenting: Vol. 2. Biology and ecology of parenting (pp. 285-309). Mahwah, NJ: Lawrence Erlbaum Associates.

Maccoby, E. E. (1998). The two sexes: Growing up apart, coming together. Cambridge, MA: Belknap Press of Harvard University Press.

Marks, L. (2001, November). Religion, families, and fathers: A review and new conceptualization. Paper presented at the Theory Construction and Research Methodology Workshop of the National Council on Family Relations, Rochester, NY.

Marks, L. D., \& Dollahite, D. C. (2001). Religion, relationships, and responsible fathering in Latter-day Saint families of children with special needs. Journal of Social and Personal Relationships, 18, 625-650.

Marsiglio, W. (1991). Paternal engagement activities with minor children. Journal of Marriage and the Family, 53, 973-986.

Marsiglio, W. (1995). Fathers' diverse life course patterns and roles: Theory and social interventions. In W. Marsiglio (Ed.), Fatherhood: Contemporary theory, research, and social policy (pp. 78-101). Thousand Oaks, CA: Sage.

Marsiglio, W., Amato, P., Day, R. D., \& Lamb, M. E. (2000). Scholarship on fatherhood in the 1990s and beyond. Journal of Marriage and the Family, 62, 1173-1191.

Marsiglio, W., \& Cohan, M. (2000). Conceptualizing father involvement and paternal influence: Sociological and qualitative themes. In H. E. Peters \& R. Day (Eds.), Fatherhood: Research, interventions and policies (pp. 75-95). New York: Haworth.

McHale, S. M., \& Huston, T. L. (1984). Men and women as parents: Sex role orientations, employment, and parental roles with infants. Child Development, 55, 1349-1361.

Mercer, R. T. (1985). The process of maternal role attainment over the first year. Nursing Research, 34, 198-204.

Meyer, S. A. (1999). Mothering in context: Ecological determinants of parent behavior. Merrill-Palmer Quarterly, 45(2), 332-357.

Minton, C., \& Pasley, K. (1996). Fathers' parenting role identity and father involvement: A comparison of nondivorced and divorced nonresident fathers. Journal of Family Issues, 17, 26-45.

Muller, C., \& Kerbow, D. (1993). Parent involvement in the home, school, and community. In B. Schneider \& J. S. Colemen (Eds.), Parents, their children, and schools (pp. 13-42). Boulder, CO: Westview.

Newman, P. R., \& Newman, B. M. (1988). Parenthood and adult development. In R. Palkovitz \& M. B. Sussman (Eds.), Transitions to parenthood (pp. 313-338). New York: Haworth.

Nock, S. J. (1998). Marriage in men's lives. New York: Oxford University Press.

Palkovitz, R. (1980). Predictors of involvement in first-time fathers. Dissertation Abstracts International, 41 (096). (UMI No. 705-801)

Palkovitz, R. (1984). Paternal attitudes and fathers' interaction with their 5-month-old infants. Developmental Psychology, 20, 1054-1060.

Palkovitz, R. (1994, November). Men's perceptions of the effects of fathering on their adult development and lifecourse. Paper presented at the meeting of the National Council on Family Relations, Minneapolis, MN.

Palkovitz, R. (1996). Parenting as a generator of adult development: Conceptual issues and implications. Journal of Social and Personal Relationships, 13, 571-592.

Palkovitz, R. (1997). Reconstructing "involvement": Expanding conceptualizations of men's caring in contemporary families. In A. J. Hawkins \& D. C. Dollahite (Eds.), Generative fathering: Beyond deficit perspectives (pp. 202-206). Thousand Oaks, CA: Sage.

Palkovitz, R. (2002a). Involved fathering and child development: Advancing our understanding of good fathering. In C. Tamis-LaMonda \& N. Cabrerra (Eds.), Handbook of father involvement (pp. 119-140). Hillsdale, NJ: Lawrence Erlbaum Associates.

Palkovitz, R. (2002b). Provisional balances: The dynamics of involved fathering and men's adult development. Hillsdale, NJ: Erlbaum.

Palkovitz, R., Christiansen, S. L., \& Dunn, C. (1998). Provisional balances: Fathers' perceptions of the politics and dynamics of involvement in family and career development. Michigan Family Review, 3, 45-64.

Palkovitz, R., \& Copes, M. (1988). Changes in attitudes, beliefs and expectations associated with the transition to parenthood. In R. Palkovitz \& M. B. Sussman (Eds.), Transitions to parenthood (pp. 183-199). New York: Haworth.

Palkovitz, R., \& Palm, G. (1998). Fatherhood and faith in formation: The developmental effects of fathering on religiosity, morals, and values. Journal of Men's Studies, 7, 33-52.

Parke, R. (2002). Fathers and families. In M. H. Bornstein (Ed.), Handbook of parenting (2nd ed., pp. 27-73). Mahwah, NJ: Erlbaum.

Parke, R., \& Beitel, A. (1988). Disappointment: When things go wrong in the transition to parenthood. In R. Palkovitz \& M. B. Sussman (Eds.), Transitions to parenthood (pp. 221-265). New York: Haworth. 
Parke, R., \& Brott, R. (1999). Throwaway dads. Boston: Houghton Mifflin.

Pedersen, F. A. (1975, August). Mother, father, and infant as an interactive system. Paper presented at the annual convention of the American Psychological Association, Chicago, IL.

Petersen, J., \& Zill, N. (1986). Marital disruption, parent-child relationships, and behavior problems in children. Journal of Marriage and the Family, 48, 295-307.

Peterson, G. W., \& Rollins, B. C. (1987). Parentchild socialization. In M. B. Sussman \& S. K. Steinmetz (Eds.), Handbook of marriage and family (pp. 471-507). New York: Plenum.

Pleck, J. H. (1997). Paternal involvement: Levels, sources, and consequences. In M. E. Lamb (Ed.), The role of the father in child development (3rd ed., pp. 66-103). New York: John Wiley \& Sons.

Popenoe, D. (1996). Life without father. New York: Basic Books.

Pridham, K., Denney, N., Pascoe, J., Chiu, Y., \& Creasey, D. (1995). A study of mothers' solutions to child-care problems. Journal of Marriage and the Family, 57, 785-799.

Purrington, B. T. (1980). The effects of children on their parents: Parents' perceptions. Unpublished doctoral dissertation, Michigan State University.

Radin, N. (1994). Primary-caregiving fathers in intact families. In A. E. Gottfried \& A. W. Gottfried (Eds.), Redefining families: Implications for children's development (pp. 55-97). New York: Plenum.

Radin, N., \& Harold-Goldsmith, R. (1989). The involvement of selected unemployed and employed men with their children. Child Development, 60, 454-459.

Radke-Yarrow, M. (1991). The individual and the environment in human behavioral development. In P. Bateson (Ed.), The development and integration of behavior: Essays in honor of Robert Hinde (pp. 389-410). Cambridge, UK: Cambridge University Press.

Radke-Yarrow, M., Nottelman, E., Belmont, B., \& Welsh, J. D. (1993). Affective interactions of depressed and nondepressed mothers and their children. Journal of Abnormal Psychology, 21, 683-695.
Rogers, S. J., \& White, L. K. (1998). Satisfaction with parenting: The role of marital happiness, family structure, and parents' gender. Journal of Marriage and the Family, 60, 293-308.

Rossi, A. S., \& Rossi, P. H. (1990). Of human bonding: Parent-child relations across the life course. Hawthorne, NY: Aldine.

Rubin, R. (1984). Maternal identity and maternal experience. New York: Springer.

Sameroff, A. (1975). Early influences on development: Fact or fancy? Merrill-Palmer Quarterly, 21, 267-294.

Schaffer, H. R. (1984). The child's entry into a social world. London: Academic Press.

Simons, R., Whitbeck, L., Conger, R., \& Melby, J. (1990). Husband and wife differences in determinants of parenting: A social learning and exchange model of parental behavior. Journal of Marriage and the Family, 52, 375-392.

Simons, R. L., Lorenz, F. O., Wu, C., \& Conger, R. D. (1993). Social network and marital support as mediators and moderators of the impact of stress and depression on parental behavior. Developmental Psychology, 29, 368-381.

Snarey, J. (1993). How fathers care for the next generation: A four-decade study. Cambridge, MA: Harvard University Press.

Snarey, J., Son, L., Kuehne, V., Hauser, S., \& Vaillant, G. (1987). The role of parenting in men's psychosocial development: A longitudinal study. Developmental Psychology, 23, 593-603.

Snitow, A. (1992). Feminism and motherhood: An American reading. Feminist Review, 40, 32-51.

Spain, D., \& Bianchi, S. M. (1996). Balancing act: Motherhood, marriage, and employment among American women. New York: Russell Sage.

Ta, L., Kuczynski, L., Bernardini, S., \& Harach, L. (1999, April). Parents 'perceptions of children's influence within the context of the parent-child relationship. Paper presented at the Society for Research in Child Development. Albuquerque, NM.

Thomas, A., \& Chess, S. (1977). Temperament and development. New York: Brunner/Mazel.

Thurer, S. (1994). The myths of motherhood: How culture reinvents the good mother. Boston: Allyn \& Bacon.

Wilson, J. Q. (1996). The moral sense. New York: Basic Books. 
